\title{
6 \\ Top-Up: The Moral Economy of Prepaid Mobile Phone Subscriptions
}

\author{
Robert J. Foster
}

The term 'moral economy' inevitably evokes Thompson's $(1967,1971)$ argument that industrial capitalism placed unsettling demands upon workers accustomed to longstanding conventions for setting just prices and following irregular work rhythms. Thompson memorably described how the clock time of methodical wage labour required a new and severe form of thrift - a continuous effort at eliminating wasted seconds and minutes for the sake of discipline and productivity; in short, a Protestant ethic. This historical transition in both time sense and work habits was protracted, conflicted and, probably, never fully accomplished.

I orient this discussion of the use of prepaid mobile phones in Papua New Guinea to Thompson's claims about 19th-century capitalism in places like Manchester textile mills. At the same time, I keep in view Schüll's $(2005,2012)$ arresting ethnography of 21 st-century capitalism as found in places like Las Vegas casinos. New technologies of machine gambling, Schüll argues, encourage habits that are quite different from those we usually associate with Puritan self-discipline. Digital game designers stimulate and enable trancelike consumption without interruption, not only accelerating the pace of play but also extending its duration. Gamers 
are led, not unwillingly, into a twilight zone where the goal of playing is to continue playing rather than to win. Play, not work, becomes the site for extracting profit.

There is, of course, no radical discontinuity between Thompson's and Schüll's accounts: capitalism remains capitalism. The generation of surplus value is now and always has been a matter of time management - squeezing profit from every available moment. But the socio-technical capacity to extract ever more surplus value from leisure activities such as gambling has brought about the paradoxical situation that I aim to describe here. That is, in Papua New Guinea, it would seem that a recognisably Protestant ethic emerges as a form of self-defence on the part of mobile phone users against the almost incessant corporate incitement to consume.

This chapter ethnographically describes tensions that inhere in companyconsumer relations around the mobile phone in Papua New Guinea. ${ }^{1}$ It documents how Digicel, the dominant mobile phone service provider, promotes ever new ways for consumers to spend more money on voice calls, text messages and, increasingly, data credits; and it documents how mobile phone users seek ways to avoid paying rent for use of Digicel's selfproclaimed 'bigger and better network'. I argue that prepaid subscriptions can and should be understood as an unstable market device comparable to technologies of machine gambling designed to stimulate game playing and perforce extract greater amounts of revenue from players. This process of extraction paradoxically encourages and undermines temporal discipline; it shapes the practices of mobile phone users, although not without public criticism and creative resistance. By this account, the use of mobile phones signals a larger project of 'managing modernity' (Patterson and Macintyre 2011) in which Papua New Guineans negotiate the terms of their moral and material futures, or so-called development.

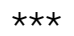

1 This chapter builds upon the conceptual framework of a collaborative research project designed and conducted with Professor Heather Horst (University of Sydney/RMIT University). Our project, funded by the Australian Research Council (DP140103773), is called 'The Moral and Cultural Economy of Mobile Phones in the Pacific'. It involves historical and ethnographic research in Papua New Guinea and Fiji organised in terms of a comparative study of relations between and among companies, state actors and consumers (see Foster and Horst, Introduction). 
In Papua New Guinea, the use of mobile phones is underwritten mainly by prepaid subscriptions that enable poor people to purchase mobile phone services on a pay-as-you-go basis (see Donner 2015). Such an arrangement has facilitated the rapid spread and uptake of mobile phones throughout the Global South, where users commonly 'top-up' their air time by purchasing small amounts, often in the form of scratch cards sold by street vendors (Figure 22). Telecommunications companies thus avoid the problem of uncollected bills for services already rendered.

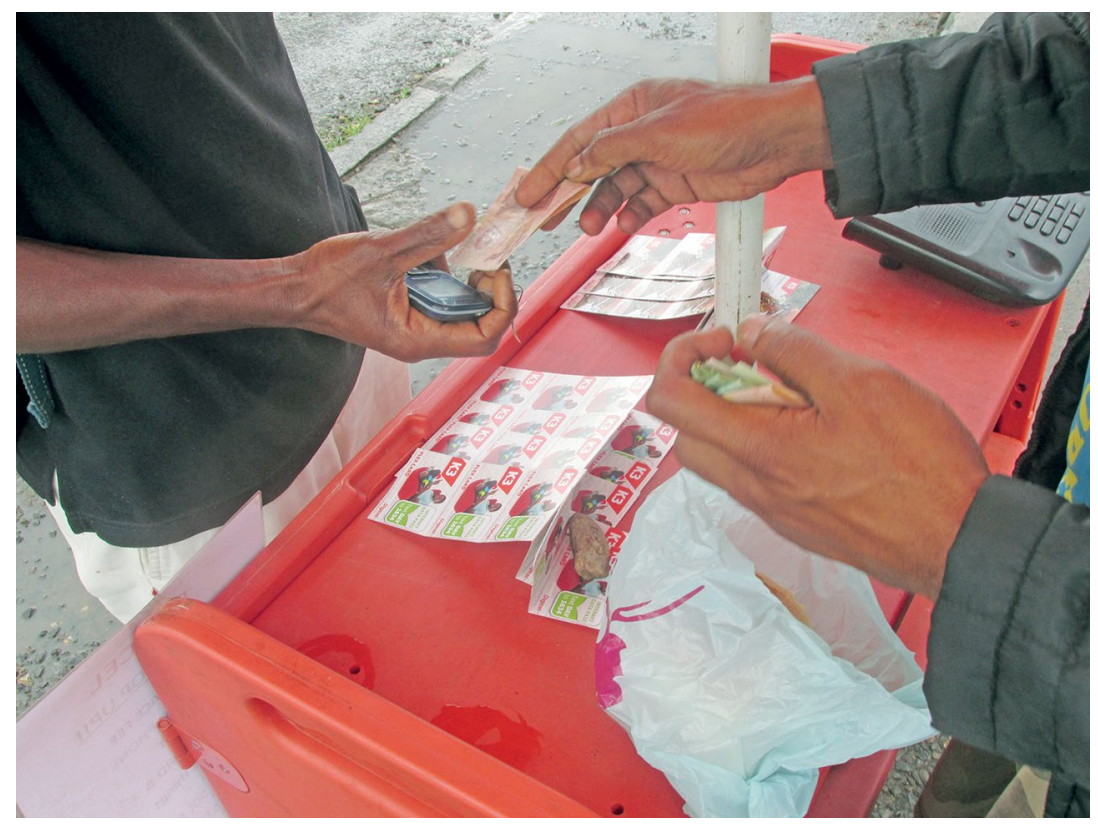

Figure 22. Top-up transaction, Goroka, Papua New Guinea, 2015

Source: Photo by W. Magea

Less acknowledged, however, is how prepaid subscriptions entail a particular moral economy in which mobile users assume fiscal responsibility for managing their phone credits. This responsibility involves dealing not only with the inevitable terms and conditions of use dictated by mobile network operators (MNOs), but also with the frequent enticements issuing from MNOs to increase and accelerate consumption. Put differently, personal discipline is intrinsic to the model of prepayments. 


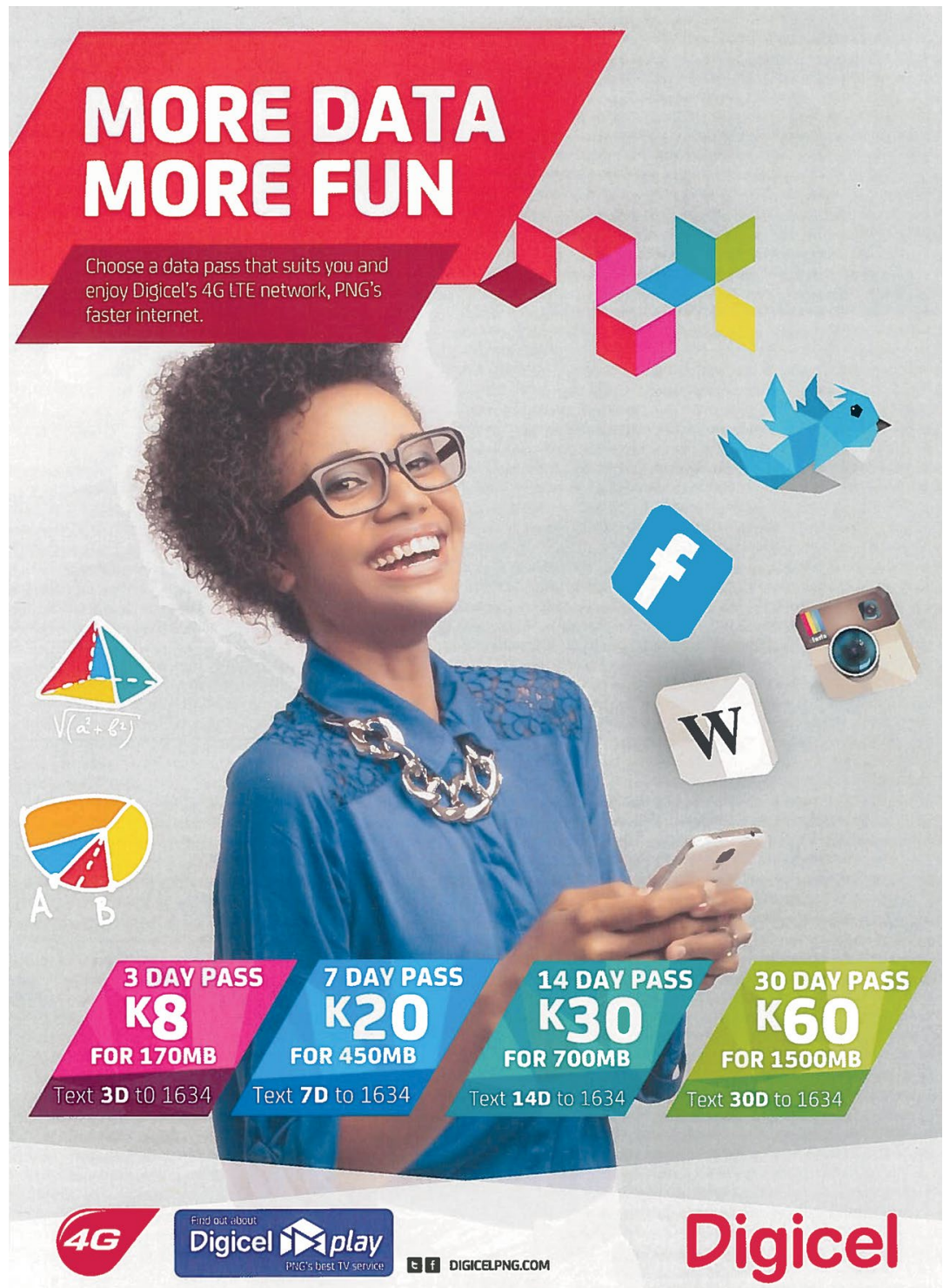

Only avallable to Digicel Prepaid Non-8lackberry Subscribers. 3Day Pass is valid for 3 days, 7 Day Pass is valid for 7 days, 14Day Pass is valid for 14 days, 30 Day Pass is valid for 30 days. Digicel Terms and Conditions (at www.digicelpng.com) apply.

Figure 23. Data bundles in different amounts and durations

Source: Digicel Group Limited

First, discipline is structural. The basic terms and conditions of prepaid subscriptions impose definite constraints. One is of course able to use only airtime that one has already paid for, but one also must use the airtime one has paid for within a certain period of time or else forfeit it. Digicel PNG 
airtime credits expire after 30 days, although they might be preserved by topping-up one's balance before the expiration date. Likewise, subscriber identity modules (SIM cards) expire when they have not been used for a certain period of time that might range up to one full year. In Papua New Guinea, Digicel SIM cards expire after three months. It is also worth noting that the sale of data credits for use on laptop computers or mobile phones is also organised in terms of expiration dates. In Papua New Guinea in 2015, one could buy data credits from Digicel that could be used for one hour (10 megabytes (MB) for 99 toea) or for 30 days (1,500 MB for 60 kina) with several options in between (Figure 23). ${ }^{2}$ Each option, however, comes with the caveat of 'use it or lose it'. That is, prepayment applies a temporal discipline upon subscribers, one that strongly encourages if not actually enforces consumption. A colleague of mine accordingly confessed that she would stay awake streaming videos on her laptop when she knew that her data credits were about to expire, despite the fact that she had no real interest in the videos and always seemed to regret her decision the following morning.

Second, discipline is subjective, in all senses of the term. Prepaid subscriptions devolve responsibility for managing credits upon the individual using the phone; they encourage the formation of what Donner (2015: 123) calls a 'metered mindset'. One must regularly check the balance of one's account; be aware of the length of calls and whether they are being charged at peak or off-peak rates, or at on- or off-network rates; and be aware of when precisely a data bundle will expire - after which time one's phone credits will be charged at very steep 'out-ofbundle' rates (Digicel currently charges 49 toea per $\mathrm{MB}$ ). It is up to the individual, not the company, to ensure that he or she has the capacity to make a call or to go online. And that includes, by the way, making sure that the phone's battery is charged, a condition never taken for granted by the vast majority of Papua New Guineans who have uncertain and limited access to electricity (Wardlow, Chapter 2).

Mobile phones, in other words, are devices for promoting a sense of time thrift, an overriding consciousness of the fact that time is money. Lucy, a woman from Bougainville now living in Eastern Highlands Province, told me that Bougainvilleans speak slowly: 'Helllooooo. How are you dooooing?,' she mimicked. She then admitted that, whenever speaking with her family in the village, she is constantly thinking, 'Hurry up! Talk

2100 toea equals 1 kina. 1 kina was equal to US\$0.33 in 2016. 
quickly! This is costing me!' It is in this regard, I suggest, that mobile phones are effective instruments for teaching an apprehension of time that would please a Puritan - certainly more effective than the discipline of industrial factory labour, which is about as rare these days in Papua New Guinea as it is in the United States. (It is hardly surprising that Digicel was able to create goodwill in many of the Caribbean markets it first entered by offering per-second billing for calls instead of charging by rounding up to the nearest 30 seconds or minute.) Moreover, the sort of personal discipline that mobile phones encourage recalls other technologies - such as self-help programs (Bainton 2010, 2011) and fastmoney schemes (Cox 2011, forthcoming) - that Papua New Guineans have embraced in search of financial viability and moral legitimacy.

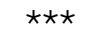

Technologies of prepayment are attracting the attention of scholars working at the intersection of anthropology, geography and science and technology studies (see, for example, Anand 2011, 2014; Baptista 2015; van Heusden 2008; von Schnitzler 2008, 2013). At its most strident, this literature condemns prepayment as a tool of neoliberal governance. Technologies of prepayment - the water and electric meter - depoliticise state-society relations by allowing the state to distance itself from its responsibilities toward citizens. Disconnection from collective services, so the argument goes, becomes self-disconnection - that is, the responsibility of individual 'customers'. These technologies, moreover, are said to inculcate economic rationalities and calculative agency. Von Schnitzler (2008: 902) thus suggests that the prepaid meter, introduced as part of a scheme to privatise water provision in post-apartheid South Africa, is 'central not only to making water calculable, but, more fundamentally, to creating a calculative rationality'. Technologies of prepayment, in other words, entail 'the configuration of economic actors' with specific capacities (von Schnitzler 2008: 902), including the capacity to commensurate social relations with monetary value.

Can any of this be said of prepaid mobile phone subscriptions? I advise proceeding cautiously. There is complexity and nuance in the actual practice of prepaid mobile phone users, and that is what an ethnographic approach promises to highlight. Horst and Miller's (2006) pioneering research on mobile phones in Jamaica, for example, demonstrates that calculability of relationships makes good cultural sense, and certainly is not the result of encroaching marketisation. Quick 'link ups' in Jamaica are 
normal (Horst and Miller 2005); the fact that an average phone call lasts 19 seconds is not a function of the exigencies of prepayment, but rather the preferred form of keeping multiple relationships open and active.

Do, then, prepaid subscriptions configure economic actors in predictable ways? The everyday use of mobile phones in Papua New Guinea suggests a relationship between consumers and companies that is more messy and less clear-cut than some critiques of neoliberalism would allow. For example, while prepayment does seem to encourage a calculating fiscal responsibility on the part of consumers, the companies providing mobile phone services routinely stimulate subscribers to consume more and more - and in less time. This stimulation, at least in the case of Digicel, derives from the exigencies of continued growth. That is, as the company runs out of new markets to enter in the Global South, it becomes more dependent on a finding a way to get existing users to spend more (Mirani 2013).

In Papua New Guinea and elsewhere, Digicel has endeavoured to put affordable (subsidised) smartphones in the hands of as many people as possible and to offer users a variety of data packages tailored to the budgets of some of the world's poorest consumers. The rapid replacement of basic handsets by smartphones in Papua New Guinea - approximately 700,000 to 800,000 subscribers in early 2016 according to one Digicel official (pers. comm., May 2016) - recalls the analogy with technologies of gambling. Machines designed to both speed up and prolong game playing - for example, by replacing pull handles with push buttons - perforce extract greater amounts of revenue from players. Ditto smartphones. But, as I will show, even users of basic handsets are regularly exhorted to consume. Prepaid subscribers can respond to this stimulation variouslyby creatively working around the costs involved in consuming more or by imposing new forms of discipline on themselves and on their associates, including friends and family members. What does this dance of stimulus and response look like in everyday practice in Papua New Guinea?

I draw here on ongoing fieldwork in Port Moresby (the capital city) and the town of Goroka (in Eastern Highlands Province) that has involved, among other things, formally and informally interviewing a range of approximately 25 mobile phone users (men and women, young and old, rural and urban) and asking approximately two dozen university students to keep detailed diaries of their phone use over a period of 48 hours. 


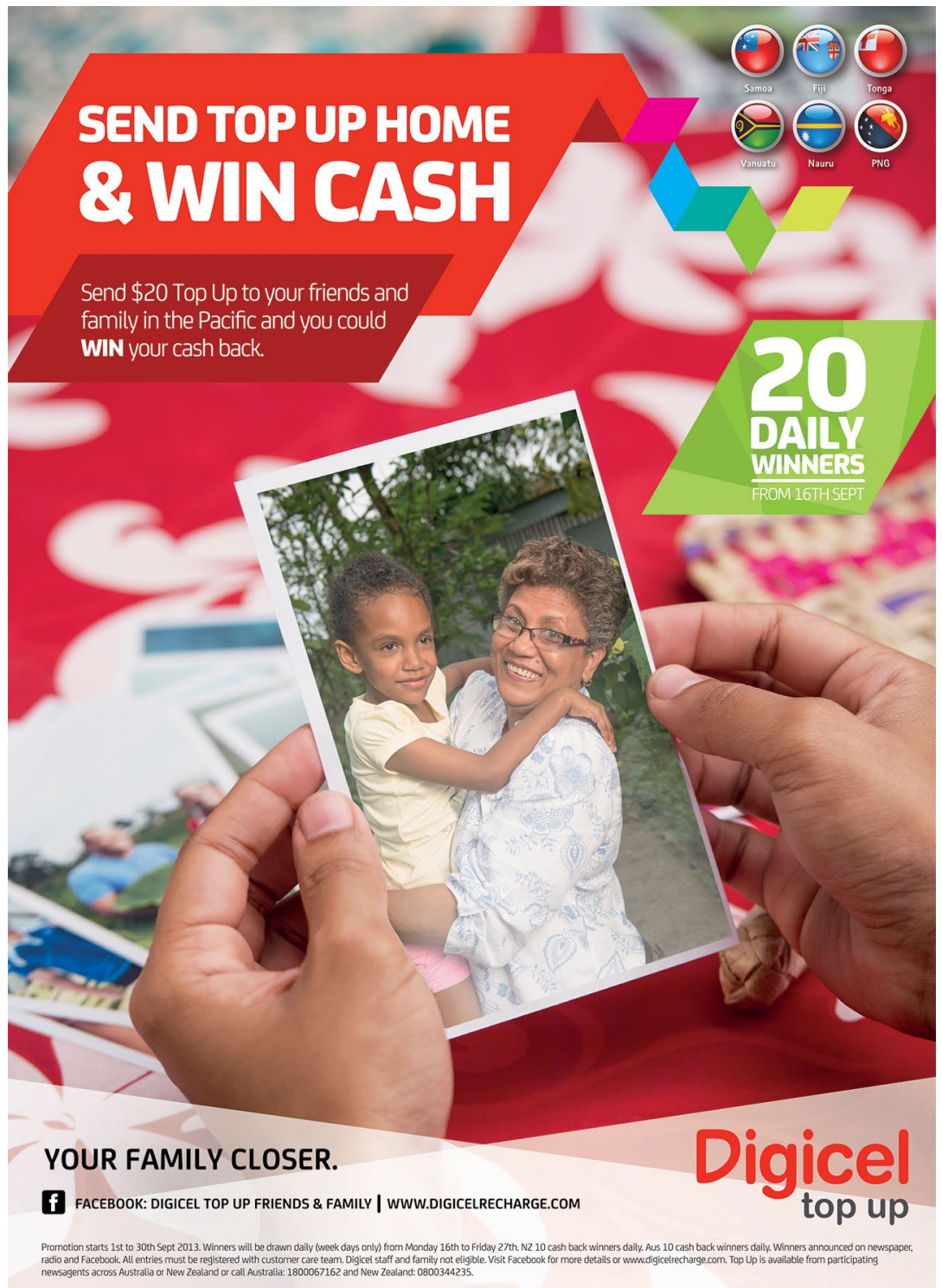

Figure 24. Your family closer: Top-up from overseas

Source: Digicel Group Limited

Research findings overwhelmingly indicate that most people (not just students) have little or no credit on their phone at any given time. Amounts of less than 1 kina are not uncommon. But a low balance or even zero credit does not mean that users are unable to access the Digicel network. In fact, the company enables such access by inviting users to 
draw on the resources of their social networks by taking advantage of a variety of services. These invitations now encourage subscribers to reach out to friends and family living in Australia and New Zealand, who can go online to top-up the phone accounts of loved ones in Papua New Guinea. Two or three times extra credit is sometimes offered as an incentive and bonus for sending these overseas gifts (Figure 24).

Within Papua New Guinea, users can make a free call to another number to request a return call (Figure 25). This service was imported into Papua New Guinea from the Caribbean, where it was introduced in response to an organically developed version of 'call me' - the missed call. In Jamaica, the introduction of this service in 2004 was welcomed as a clear sign that Digicel understood and respected how Jamaicans communicate with each other.

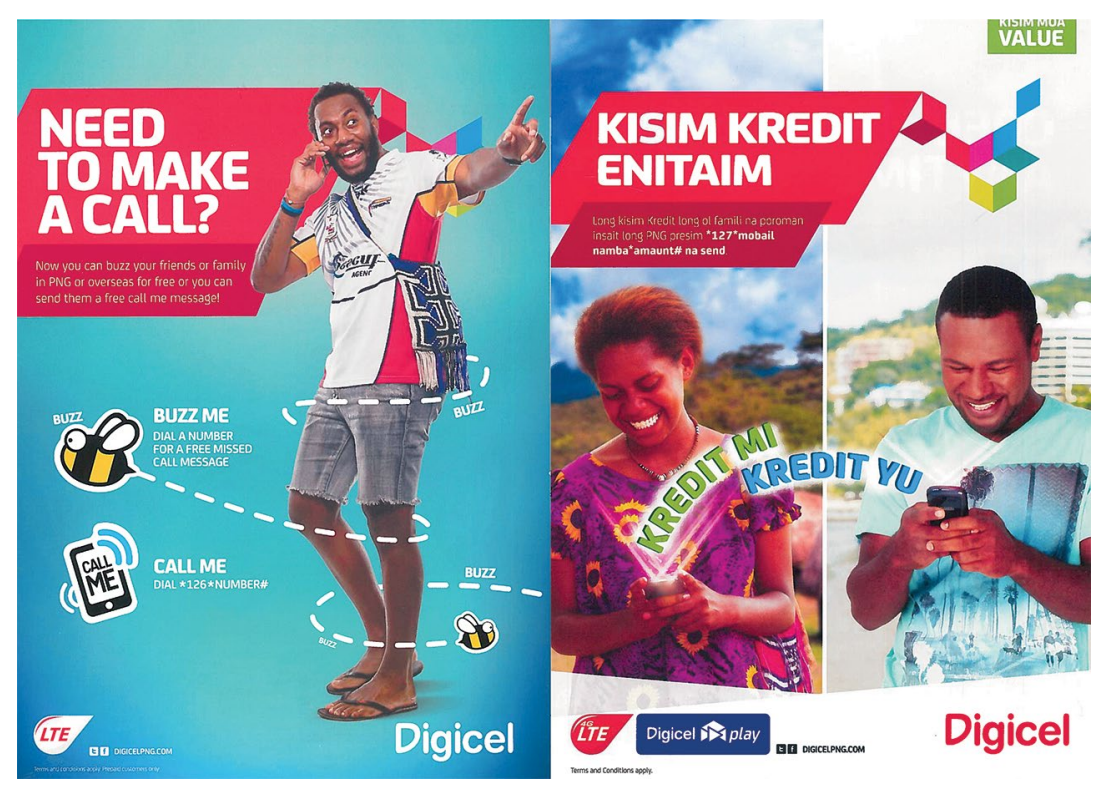

Figure 25. Call me. Credit me

Source: Digicel Group Limited

In addition, users can send requests for specific amounts of credit from 1 to 99 kina (Figure 25). Credit can be sent directly to another phone for a service charge of 30 toea. Research findings suggest that almost everyone uses this service. Regular credit exchanges of small amounts are a common feature of boyfriend/girlfriend relationships among university students, who also request larger amounts of credit from their parents with similar 
frequency. Kraemer (Chapter 5; see also Kraemer 2015) has documented the importance of these credit requests and exchanges for the maintenance of social networks among urban youth in Vanuatu, where Digicel also figures as the dominant MNO.

It is also important, however, to note that call me and credit me requests are not always met. (Indeed, the low balances that people keep on their phones can plausibly be interpreted as a strategy for protection against credit requests - a strategy that recalls traditional practices for safeguarding one's resources [betel nut, tobacco, garden produce, shell valuables] from the claims of others [Foster 1993].) One interviewee thus stated that he does not answer any of the requests that he receives because, if a person has a mobile phone, then that person should be able to afford to operate it. Here, in other words, is evidence of a discourse of self-responsibility taking shape around mobile phones - exactly the sort of discourse critics of neoliberalism might anticipate. At the other extreme, however, Lucy, the woman from Bougainville, claimed that she responds to all requests and even sends credits to friends and family unsolicited. She explained that she was the firstborn in her family and had numerous siblings and other relatives to look out for.

In many instances, people meet requests selectively, deciding when it is appropriate to respond positively and to whom. For example, one woman explained that she responds to her children's call me requests, but not to their credit me requests. She is willing to pay to speak with her children, but not to finance their communication with other people. This response also reflects what some critics of neoliberalism understand as the extension of economic rationality into the domain of the social - that is, the calculation of social relationships in terms of the price of airtime.

Call me and credit me - the company's attempts to extract rent for using the network from someone else if not the actual user - are also met with a kind of creative resistance. Assertions of autonomy - of what one might imagine as the right to communicate - take the form of avoiding service charges or even free riding on the network. For example, one can use free credit requests for specific amounts to send coded messages, many of which have been documented by Olga Temple and her students at the University of Papua New Guinea (Temple et al. 2009). Among the more popular requests are: 99 kina (Goodnight), 43 kina (Love you), 60 kina (Hurry up!) and 24 kina (I have no credit). A request for 24 kina can be sent in polite response to a call me or credit request that one prefers not to accept. 
More ambiguous with respect to the question of agency - calculative and otherwise - are the promotions by which the company gives users the means to avoid some but hardly all of the structural limits built into prepaid subscriptions. For example, one much-discussed Digicel promotion rewards users who top-up their balances in the amount of 5 kina or more. A user will receive from Digicel the following text message: 'Congratulations! You have been rewarded with $100 \mathrm{~min}$ talk time bundle. 100 mins valid for local mobile calls between 11PM-7AM.' These minutes can only be used beginning $11 \mathrm{pm}$ on the day that one tops-up; the bundle will expire at 7 am the next morning.

This particular promotion provokes strange mixtures of discipline and excess that confound any easy answer to the question of what sort of fiscal subjects are constructed by prepaid subscriptions. The notion of time thrift - at least as any Puritan would recognise it - seems perverted when people stay awake until the wee hours of the morning to make phone calls. Indeed, this aspect of the promotion has received public criticism from parents complaining that their children are staying up too late on school nights. I recall one sardonic letter to a newspaper asking whether Digicel thought the author was a flying fox, expecting him to be awake for conversations at $3 \mathrm{am}$.

On the other hand, time thrift and calculative agency are undeniably present. Users defer making calls during peak-rate periods in order to take advantage of the promotion. One tired young man reported to me that he had received a call from a friend at $1 \mathrm{am}$. When he anxiously asked the friend if anything was wrong, the friend explained that all was well, but he just did not want to 'waste' the free minutes he received through the promotion. This sort of time thrift risks provoking a negative response for reasons besides disturbing people's sleep. One young woman thus observed that she would not be pleased if her boyfriend called her with free minutes, since it would imply that she was not worth the call otherwise. The currency of phone credits here again measures the value of intimacy. ${ }^{3}$

3 This promotion also stimulates the annoying practice of making random calls, sometimes repeatedly to the same number, in search of cross-sex 'phone friends' (Andersen 2013; Jorgensen 2014). 
Another popular promotion invites users to purchase a discounted bundle of 60 text messages for K1.20, with the bundle expiring at midnight. Most people with whom I have spoken refer to these text messages as 'free', although economic rationality would insist that each text costs 2 toea (and are advertised by Digicel as such). This particular promotion was one step in a process that illustrates how users are induced to increase consumption. In 2014, a similar promotion offered 50 text messages for 75 toea. (Texts at the time were billed at 25 toea each for the first three, then 6 toea for each text thereafter until midnight; they are now billed at 25 toea per message.) The bundle of 60 text messages thus encourages people to send more texts at a higher price per text. In fact, the promotion encourages the sort of phatic communication in which the message is less important than the act of sending it. Across Papua New Guinea, lots of 'have a top day' and 'good night' messages circulate, especially as the hour of the bundle's expiration draws close. Indeed, some people found 60 texts to be far more than they might need; and others complained that the K1.20 price meant that receiving a gift of 1 kina credit was no longer enough to purchase a text message bundle. ${ }^{4}$

In January 2016, after it was suspended during the Christmas holiday to ensure network stability, the 60 SMS Bundle was relaunched with several new features (Figure 26). The bundle is now valid for 24 hours rather than expiring at midnight. It also auto-renews, allowing the user to carry over unused text messages, unless the user sent a text message to opt out of auto-renewal. It thus becomes the duty of each user to make sure that credit is not unexpectedly deducted from his or her airtime balance. This auto-renew function has also become a standard feature of prepaid data plans, adding one more task to the increasingly complicated management of data on smartphones. While many users complain that their data is disappearing or even being stolen by Digicel (see Foster 2016), the company suggests that users must learn how to manage the settings on their smartphones, turning off the auto-sync function, for example, or remembering that music streaming might use up to $1 \mathrm{MB}$ per minute. That is, Digicel responds to the concerns of its users over how the company measures usage and charges for data with exhortations to assume greater individual responsibility for operating personal devices. Digicel has gone

4 In April 2016, I received the following text message several times over the course of a week in Port Moresby, once at 4.57 am: 'The Xpress bundle has arrived! Send Y to 16135 to get 200 SMS + $10 \mathrm{MB}$ of Data for K2 valid for 24 hours! Bundle comes with auto-renew. More value with Digicel!' 
so far as to offer 'Smartclinics' at its retail outlets in order to educate the public in matters of data usage and social media. The smartphone thus seemingly advances the development of everyday forms of neoliberal governance already entailed in prepaid subscriptions for basic handsets.

\section{SMS Bundle}

Digicel to Digicel Mobile SMS Bundle: (Amended and Effective: 19th November 2015)

60 SMS Bundle now Auto-Renews so you carry over your remaining un-used SMS over to your new SMS bundle. Now, the 60 SMS Bundle is valid for 24 hours, that's 24 hours to text all day and night! And you can subscribe multiple times.

\begin{tabular}{|l|c|c|c|}
\hline \multicolumn{1}{|c|}{ Bundle } & $\begin{array}{c}\text { Price (PGK) GST } \\
\text { Inclusive }\end{array}$ & SMS Count & Validity \\
\hline 60 SMS Bundle & K1.20 & 60 & 24 hours \\
\hline
\end{tabular}

To subscribe to the SMS bundle, send a blank message or the keyword 'SMS' to 1629. SMS Bundle will auto-renew 24 hours from time of purchase. To stop auto-renew, text 'STOP' to 1629.

60 SMS Bundle only applicable for Digi to Digi SMS.

Check your bundle balance at any time by dialing *130\#.

Figure 26. 60 SMS Bundle

Source: Digicel Group Limited

The main point at stake in examining the practical details of managing prepaid subscriptions is the same one that Mintz (1985) made about sugar in his book Sweetness and Power. Demand for sugar is not to be taken for granted, notwithstanding any primate predisposition to consume the stuff. Demand is the outcome of struggles between producers and consumers, struggles that also involve state actors in the form of subsidies, tariffs and trade policies. Much the same can be said for mobile phone services. Demand for mobile phone services is in large measure an outcome of contests in which companies seek ways to undo the fiscal responsibility that consumers learn, ironically, through the pedagogy of prepaid technology.

One logical response to Digicel's promotions and strategies - to its efforts to stimulate more consumption of voice, SMS and data - is greater self-imposed discipline. Let me offer again the example of Lucy, not as typical of Papua New Guineans, but as illustrative of the way in which autonomy and dependence, self-discipline and self-indulgence, merge in the everyday micro-practices of operating a mobile phone. Lucy is 
a heavy user who can spend up to 100 kina a week in airtime credits. She is a young single woman living far from home and regards frequent communication with her family and friends as nothing less than essential. Lucy, who has a steady income, is aware that she is capable of spending all her savings on airtime, and she has on occasion come close to doing so by topping-up her phone through a mobile banking account with Bank South Pacific - a relatively new service that effectively enables users to top-up any time, any place. (A fair comparison might be made here with gambling machines that provide access to a player's bank account without requiring the player to leave his or her seat in front of the machine.) In order to discipline herself - and Lucy used the English word discipline - Lucy has opened an account with another bank into which she makes weekly deposits. This bank, according to Lucy, does not offer the mobile top-up service. She has thus safeguarded her money from herself.

Lucy is explicit about the calculations that she makes in managing her mobile phone. She says that she does not feel able to start the day unless she is equipped to communicate. So, in the morning, she will top-up her phone for 5 kina. This top-up gives her the aforementioned 100 free promotional minutes to use that night starting at $11 \mathrm{pm}$. She then purchases a one-day data pass $-60 \mathrm{MB}$ for 3 kina. This data is enough to allow her to go online and communicate with friends and family via the applications WhatsApp and Viber. Lucy only recently discovered that she could send voice messages over the Internet for much less money than making voice calls. ${ }^{5}$ Finally, Lucy purchases 60 text messages for K1.20. She will use most if not all of these text messages before they expire at midnight. That leaves 80 toea as a balance in case Lucy needs to make a quick phone call during the day. (On-net calls from one Digicel phone to another are billed at 79 toea per minute during the peak weekday hours of $7 \mathrm{am}-9 \mathrm{pm}$.) Once she has made these preparations, Lucy feels ready to go out into the world and meet the demands of the day.

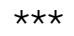

5 Since I spoke with Lucy, Digicel has changed its pricing policies: 'Effective as of the 15th December 2015, all VOIP (Voice Over Internet Protocal [sic]) calls will be charged at a rate of K1.00 per megabyte.' 


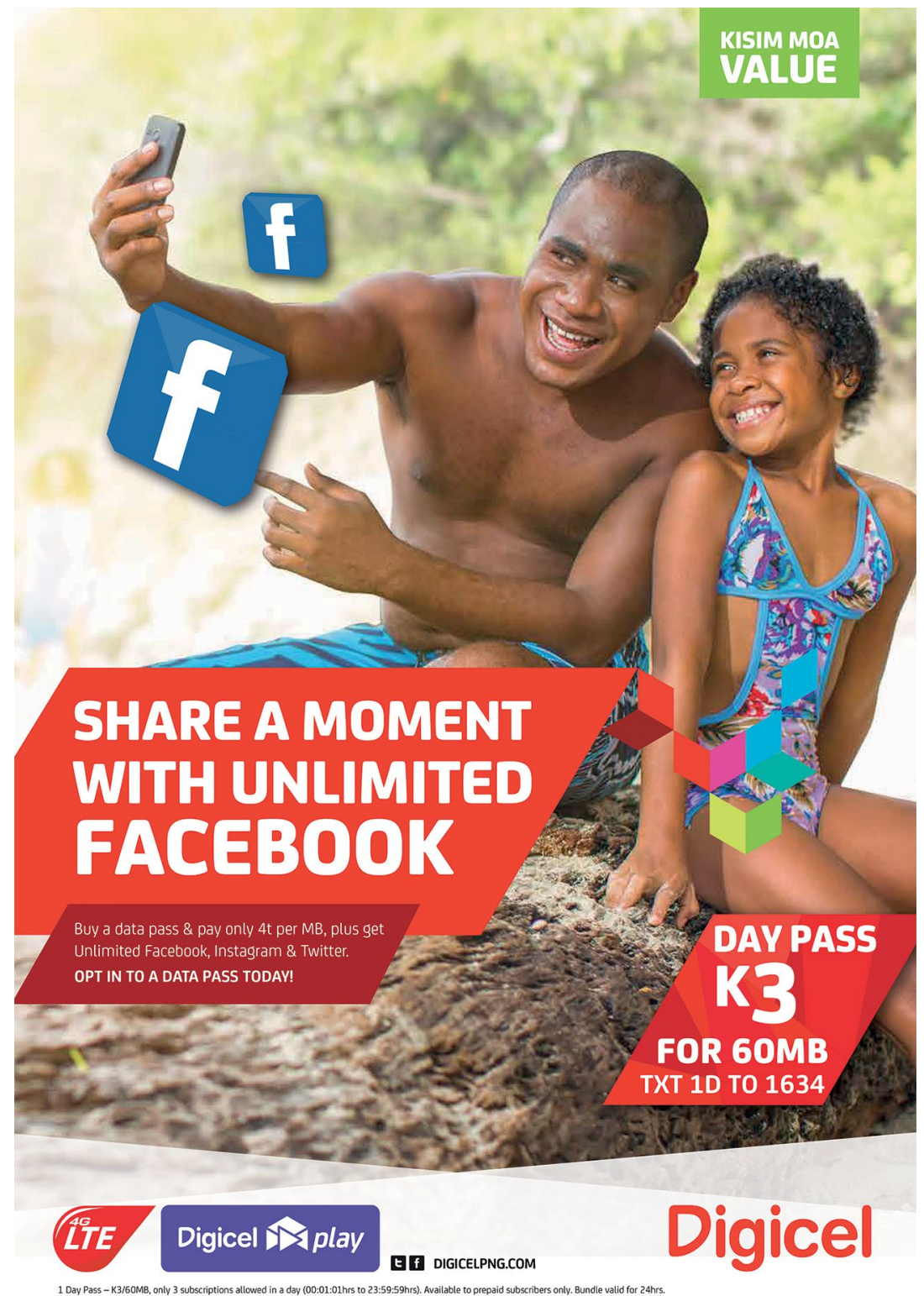

Figure 27. Data pass options

Source: Digicel Group Limited 
Thompson talked about the ways in which people became accustomed more or less - to the new valuations of time that accompanied the Protestant ethic and capitalist work discipline. Prepaid mobile phone subscriptions also subtend new valuations of time, although not in any deterministic way. They are market devices for cultivating responsible consumers responsible in the sense that these consumers pay for what they consume, and consumers in the sense that they do not simply accumulate airtime and data credits but instead actively use them, top them up and repeat the process as often as possible. Whereas the factory workers that Thompson considered were under pressure to give up all non-purposive activity, the responsible mobile phone consumer is enjoined to chat idly or surf the web. In April 2015, signalling how it imagines the source of future revenues, Digicel accordingly introduced a new data plan: for 4 kina, one can now buy a 24-hour data bundle that supplies not only $60 \mathrm{MB}$ of data, but also unlimited access to Twitter, Instagram and Facebook (Figure 27). In July 2017, Digicel introduced free Facebook basics.

Thompson (1967: 95) imagined a future in which filling one's day with 'leisurely personal and social relations' would be an alternative to and respite from work. Schüll's description of slot machine gambling complicates Thompson's vision; players - retired or, perhaps, on holiday - submit to the soft discipline of digital technologies no less than Manchester weavers conformed to the unrelenting rhythm of power looms. And, as Lucy's morning routine makes clear, enacting personal and social relations is also a form of work, one that requires discipline and that produces surplus value not unlike the labour of a factory hand.

\section{Acknowledgements}

Earlier versions of this chapter were presented at seminars at the University of the South Pacific and the University of Papua New Guinea. I thank the audiences at these seminars for their comments and suggestions. I thank the Australian Research Council for funding the research on which this chapter is based and my research partner, Dr Heather Horst, for her steady collegial support. Dr Amanda Watson provided welcome hospitality and generous support for the project. Dr Linus digim'Rina and Dr Verena Thomas helped to coordinate research assistance in Port Moresby and Goroka, respectively. I have benefited from insightful conversations with Amanda Watson, Wendy Bai Magea, Alessandra Mel, Ben Ruli, Alex 
Nava and Jason Kariwiga. While Digicel Group has permitted the use of its images and artwork, the views, opinions and research expressed in this chapter are those of the author and do not necessarily reflect the official policy or position of Digicel Group or any of its affiliates and entities.

\section{References}

Anand, N. 2011. PRESSURE: The PoliTechnics of Water Supply in Mumbai. Cultural Anthropology, 26(4): 542-64.

2014. Consuming Citizenship: Prepaid Meters and the Politics of Technology in Mumbai. Institute for Advanced Study. Occasional Papers of the School of Social Science, no. 53. www.sss.ias.edu/files/ papers/paper53.pdf (accessed 15 April 2018).

Andersen, B. 2013. Tricks, Lies and Mobile Phones: 'Phone Friend' Stories in Papua New Guinea. Culture, Theory and Critique 54(3): 318-34. doi.org/10.1080/14735784.2013.811886

Bainton, N.A. 2010. The Lihir Dstiny: Cultural Responses to Mining in Melanesia. Canberra: ANU E Press.

2011. Are You Viable? Personal Avarice, Collective Antagonism and Grassroots Development in Melanesia. In Managing Modernity in the Western Pacific. M. Patterson \& M. Macintyre, eds. St Lucia: University of Queensland Press, pp. 231-59.

Baptista, I. 2015. 'We Live on Estimates': Everyday Practices of Prepaid Electricity and the Urban Condition in Maputo, Mozambique. International Journal of Urban and Regional Research, 39(5): 1004-19. doi.org/10.1111/1468-2427.12314

Cox, J. 2011. Prosperity, Nation and Consumption: Fast Money Schemes in Papua New Guinea. In Managing Modernity in the Western Pacific. M. Patterson \& M. Macintyre, eds. St Lucia: University of Queensland Press, pp. 172-200.

forthcoming. Fast Money Schemes: Hope and Deception in Papua New Guinea. Bloomington: Indiana University Press.

Donner, J. 2015. After Access: Inclusion, Development and a More Mobile Internet. Cambridge, MA: MIT Press. 
Foster, R.J. 1993. Dangerous Circulation and Revelatory Display: Exchange Practices in a New Ireland Society. In Exchanging Products: Producing Exchange, Jane Fajans, ed. Sydney: Oceania Monograph Series, no. 43, pp. 15-31.

2016. Digicel Complaints Group: The Moral Economy of Data in Papua New Guinea. Paper presented at the 115th Annual Meeting of the American Anthropological Association, Minneapolis, 17 November.

Horst, H.A. \& D. Miller 2005. From Kinship to Link-up: Cell Phones and Social Networking in Jamaica. Current Anthropology, 46(5): 75578. doi.org/10.1086/432650

— 2006. The Cell Phone: An Anthropology of Communication. New York: Berg.

Jorgensen, D. 2014. Gesfaia: Mobile Phones, Phone Friends, and Anonymous Intimacy in Contemporary Papua New Guinea. Paper presented at CASCA: Canadian Anthropology Society Conference. York University, Toronto, 30 April.

Kraemer, D. 2015. 'Do You Have a Mobile?' Mobile Phone Practices and the Refashioning of Social Relationships in Port Vila Town. The Australian Journal of Anthropology (TAJA), 28(1): 39-55. doi.org/ 10.1111/taja.12165

Mintz, S.W. 1985. Sweetness and Power: The Place of Sugar in Modern History. New York: Viking.

Mirani, L. 2013. This Company Brought Cell Phone Service to the Remotest Countries on Earth - and Then It Ran Out of Places to Go. Quartz. qz.com/154430/this-company-brought-cell-service-tothe-remotest-countries-on-earth-and-then-it-ran-out-of-places-to-go/ (accessed 15 April 2018).

Patterson, M. \& M. Macintyre, eds 2011. Managing Modernity in the Western Pacific. St Lucia: University of Queensland Press.

Schüll, N.D. 2005. Digital Gambling: The Coincidence of Desire and Design. Annals of the American Academy of Political and Social Science, 597(1): 65-81. doi.org/10.1177/0002716204270435 
__ 2012. Addiction by Design: Machine Gambling in Las Vegas. Princeton University Press.

Temple, O., A. Apakali, D. Bai, D. Dekemba, L. John, G. Matiwat \& M. Ginmauli 2009. PNG SMS Serendipity or sma@upng.ac.pg. Port Moresby: University of Papua New Guinea Press.

Thompson, E.P. 1967. Time, Work-Discipline, and Industrial Capitalism. Past and Present, 38: 56-97.

—_ 1971. The Moral Economy of the English Crowd in the Eighteenth Century. Past and Present, 50: 71-136.

van Heusden, P. 2008. Discipline and the New 'Logic of Delivery': Prepaid Electricity in South Africa and Beyond. In Electric Capitalism: Recolonising Africa on the Power Grid. D.A. MacDonald, ed. Cape Town: HSRC Press, pp. 229-47.

von Schnitzler, A. 2008. Citizenship Prepaid: Water, Calculability, and Techno-Politics in South Africa. Journal of Southern African Studies, 34(4): 899-917. doi.org/10.1080/03057070802456821

__ 2013. Traveling Technologies: Infrastructure, Ethical Regimes, and the Materiality of Politics in South Africa. Cultural Anthropology, 28(4): 670-93. doi.org/10.1111/cuan.12032 
This text is taken from The Moral Economy of Mobile Phones: Pacific Islands Perspectives, edited by Robert J. Foster and Heather A. Horst, published 2018 by ANU Press, The Australian National University,

Canberra, Australia.

doi.org/10.22459/MEMP.05.2018.06 